\title{
"THE EVER-CHANGING \\ NATURE OF THE SEA": WHITMAN'S ABSORPTION OF MAXIMILIAN SCHELE DE VERE
}

\author{
STEFAN SCHÖBERLEIN
}

IN RECENT YEARs, Betty Barrett and Ted Genoways have discovered that Whitman lifted entire images and phrases from newspaper articles and rearranged them into some of his Civil War poems. ${ }^{1}$ This "found poetry" aspect of Whitman's poetry is not, however, confined to the Whitman of the Civil War era. Instead it began earlier and stemmed from a long-lasting fascination with a fellow writer whose influence on Leaves of Grass remains largely overlooked: Maximilian Schele De Vere, author of Stray Leaves from the Book of Nature, ${ }^{2}$ which appeared in 1855, sharing with Whitman's first edition of Leaves not only a publication date but a green cover blind-stamped with flowery ornaments and sporting a golden title. Stray Leaves has so far found its way into Whitman scholarship as nothing more than a curious footnote, ${ }^{3}$ though Schele De Vere himself has been increasingly gaining critical notice.But even though it is unlikely that this book influenced the 1855 Leaves of Grass (Stray Leaves would have been published at most only a few months before the first edition of Leaves of Grass) and the striking physical similarities between the books do appear to be coincidental, such is not the case with the 1856 and (especially) the 1860 editions of Leaves, which are significantly influenced by Schele De Vere's thinking, and which include an almost word-by-word copy of a whole paragraph from Stray Leaves - the first known instance of Whitman copying and rearranging somebody else's words into his own poetry.

Born "in a grim old mountain castle" in Sweden and raised in Prussia, baron Maximilian Schele De Vere (1820-1898) emigrated to the United States in his early twenties after receiving a degree in philosophy from Berlin's Friedrich Wilhelm Universität. In 1844, he became the youngest faculty member in the history of the University of Virginia, where he taught a variety of subjects and even volunteered as a drill sergeant during the Civil War. He published several books on natural science, comparative literature, American history, and linguistics, and he translated French and German works of fiction into English. While 


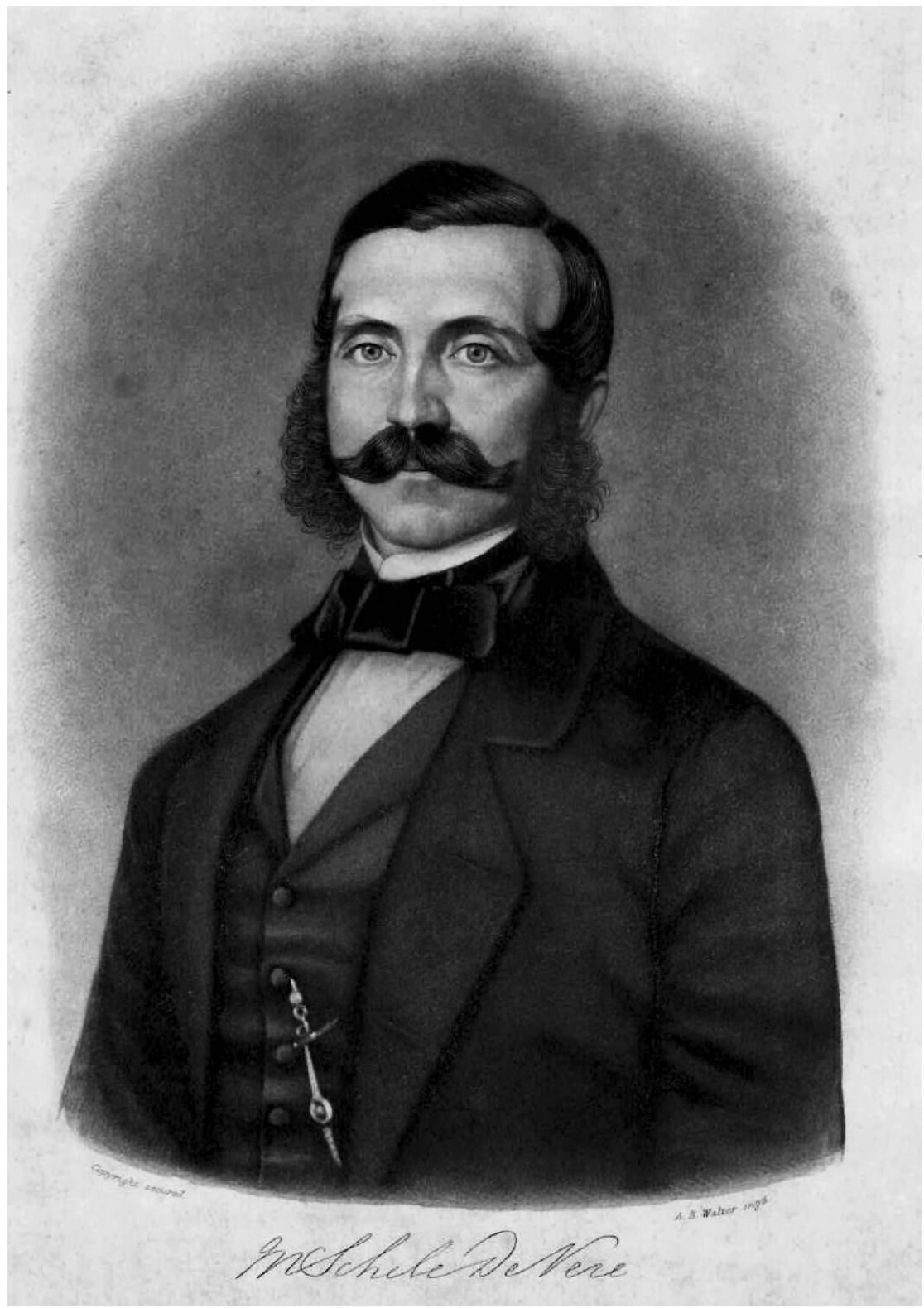

Figure 1: "M. Schele De Vere," engraved by A. B. Walter, Bohn's Album and Autographs of the University of Virginia [Manuscript]. (Charlottesville, VA: Albert and Shirley Small Special Collections Library, University of Virginia), Accession \# RG-30/1/6.062. Bohn's Album was published in 1859, but the exact date of the lithography is unknown. Because early 1850 s images show a strikingly younger-looking Schele De Vere without a beard and fuller hair, a late 1850s engraving date seems probable. 
Schele De Vere's upbringing, education, and social status could not have been more different from Whitman's, their philosophical interests overlapped on a striking number of topics. Both shared a keen interest in the American idiom (Schele de Vere was the first academic to teach classes on it), were fascinated by Eastern mythology, ${ }^{5}$ admired Darwin, Humboldt, and the heroes of the American Revolution, and tried to fuse a strict belief in natural law with spirituality. ${ }^{6}$ (See Figure 1.)

Whitman presumably discovered the scholar first through Outlines of Comparative Philology, a book Schele De Vere published through G. P. Putnam \& Co. in 1853. According to C. Carroll Hollis, Whitman borrowed the book from his acquaintance William Swinton sometime between 1856 and $1859^{7}$ and took notes on it. ${ }^{8}$ In the only academic treatment of Schele De Vere and Whitman to date, James Perrin Warren identifies striking similarities in both authors' optimistic understanding of language ${ }^{9}$ and strongly suggests that Whitman studied Schele De Vere's book. Whether Whitman came upon Schele De Vere's later writings, such as Stray Leaves, by actively searching for them or through a chance encounter remains uncertain. Considering that Whitman most likely read the periodicals Schele De Vere published in on a regular basis, it seems almost inevitable that the well-read Whitman would have rediscovered the well-published Swede at some point.

One very likely place for Whitman to have re-encountered Schele De Vere is Putnam's Monthly Magazine of American Literature, Science and Art, a periodical issued by G. P. Putnam, the publisher of both Swinton's and Schele De Vere's books. The poet would have read Swinton's "Rambles over the Realms of Verbs and Substantives"10 published in two parts in the periodical in late 1854, as well as a review of Leaves in 1855-one of the few that, besides his self-reviews, had anything positive to say about his book. ${ }^{11}$ Around the 1850 s, Whitman seemed to have taken a keen interest in the publication that would eventually merge with The Atlantic Monthly. Even in old age, he referred back to Putnam's Magazine and recalled its restructuring in $1867 .{ }^{12}$ Leafing through the 1855 and 1856 issues of Putnam's Magazine, Whitman would have stumbled over numerous articles by Schele De Vere, who published the whole of Stray Leaves as well as some other writings in the magazine, often at a rate of two or even three articles per issue. So even if Whitman did not, in the 1850s, hold in his hands Schele De Vere's book which so curiously resembled his own, he would nonetheless have encountered its contents on numerous occasions.

Why Schele De Vere's nature writings would have appealed to Whitman is neatly described in an 1855 review of Stray Leaves in the Daily National Intelligencer: 
Prof. Schele De Vere loves to look at Nature first through the dry light (lumen siccum) of Bacon, and then through the prismatic glass of Darwin. The dry and rigid facts of physical research and discovery he moulds into form and beauty . . . ${ }^{13}$

Mixing contemporary scientific truths with dark, almost gothic images of death and decay, Schele De Vere's writings of the 1850s sketch a world ruled by the "great law of Nature" (SL 57). To Schele De Vere, life is based in death: land is composed of "immense masses of . . . vegetable corpses" (SL 37) and water is full of dying animals and dead sailors. Given that there is likely no influence of Schele De Vere's writing on the 1855 edition of Leaves (or the other way around), paragraphs like the following are all the more remarkable in their affinity with Whitman's diction, imagery, and thought:

But there is Life in Death. Not in man's inspired writings only, but in every lineament, in every movement of our great mother Earth all around us, all over this globe, Death seems to stalk triumphant. The summer passes away, flowers fade and fruits decay; field and meadow are buried in deep slumber. . . . But Death has found his conqueror in Nature also. What perishes, rises again; what fades away, changes but form and shape. Sweet spring follows winter; new life blossoms out of the grave. (SL 19-20)

This idea of looking at life and death as an ever-recurring cycle of dissolving into particles and forming anew, seems to confirm Whitman's meditations in what would become "Song of Myself":

What do you think has become of the young and old men?

And what do you think has become of the women and children?

They are alive and well somewhere;

The smallest sprout shows there is really no death,

And if ever there was it led forward life, and does not wait at the end to arrest it,

And ceased the moment life appeared.

All goes onward and outward .... and nothing collapses,

And to die is different from what any one supposed, and luckier. ${ }^{14}$

Even more obsessed than the 1855 Whitman with the idea of a world made up of rotting and recycled matter, Schele De Vere devotes a whole chapter of Stray Leaves to the idea that everything beneficial that comes from the earth is essentially a resurrected cadaver. In a chapter of Stray Leaves titled "Plant-Mummies," for example, he describes the genesis of a coal vein:

... the huge ferns died a slow and silent death. One by one they would sink, weary of life and worn out by the fierce storm all around them, until gentle rains came, and 
with tender sympathy, spread a pall of white sand and bright colored stones over their buried bodies. . . . But tenderly as nature had covered their dead bodies, still their race was not yet run, their purpose but half fulfilled. Tree by tree, and herb by herb, they lay peacefully in their grave. . . . But now, after centuries, man came and made his way through vast layers of clay and firm strata of rock. . . He brought them forth, the corpses of long forgotten plants, to the light of a sun they had never seen before; he made their remains to work for him-his busiest servants, his most efficient slaves. (SL 236-237)

By seeing the earth as bloated with rotting matter, Schele De Vere both joins in and rejects contemporary notions of miasma, a primitive predecessor of germ theory that blamed the foul odor of decay for death and infections, leading often to-by today's standards - absurd claims as put forward, for example, in this 1848 article describing a choleraoutbreak in London:

There is in fact a poison floating in the air (of London) which causes death. It is not gas, but a sort of atmosphere of floating particles. . . This diseased mist . . f from open sewers and cesspools, graves and slaughter-houses, is continually kept up and undergoing changes. ${ }^{15}$

Though Schele De Vere accepts the general idea of "bad air disease"-it was, after all, the scientific status quo ${ }^{16}$ - he redefines it to a degree that is closer to modern ideas of water eutrophication than to a theory with possibly apocalyptic implications (given the rising number of dead). Instead of humanity eventually succumbing to bad air, Schele De Vere argues that wind, the tides, and a consequent natural repurposing of nutriment-rich "grave sites" actually prevent miasmic mass death. This "general law of movement" that "no class of animals, high or low, escapes entirely" (SL 59), Schele De Vere demonstrates by looking at the ocean:

Without this ever-stirring activity in its own bosom, without this constant moving and intermingling of its waters, the countless myriads of decaying plants and animals which are daily buried in the vast deep, would soon destroy, by their mephitic vapors, all life upon earth. (SL 93)

While it is uncertain if Whitman had read Stray Leaves before publishing his 1856 edition of Leaves of Grass, he would have discovered this essay in Putnam's Monthly in July of $1855 .{ }^{17}$ It is very likely that Whitman read this article, with its intriguing title, "Plant-Mummies," written by an author he already valued for his language writings, and published in one of the leading monthlies of his time. In it, Whitman would not only have read of "huge forests . . buried in the bosom of the earth" that are waiting "for the day of their resurrection" (SL 235) but also would have encountered the following passage: 
Man had exhausted the resources which the vegetable world of our day afforded him; every herb bearing seed, and every tree in which is the fruit of a tree, had been to him for meat. But he desired more, and his restless, insatiable mind longed for new realms and new powers. So he went back into distant ages and exhumed the bodies of ancient generations. For animals and plants both, are made faithfully to return, to their common mother earth, whatever they have taken from her. The beast of the field, and even proud man die, and dust returns to dust. Plants, also, the first-born children of the earth, must die, and return to the bosom of their great mother. But they sink only to rise again, or if buried beneath the ruins of ages, they preserve, even there, in eternal night, a breath of their former vitality, and centuries after, their dead bodies become, in the hands of man, once more a source of light and life. (SL 225)

With the scientific blessings of a scholar usually addressed by newspapers as "Prof. Schele," Whitman would have felt encouraged to develop further the ideas he had tried out in the opening poem of the 1855 Leaves. The image of mankind eating the "exhumed bodies of ancient generations" (SL 225), coupled with Schele De Vere's critical reassessment of the theory of miasma, is strongly echoed in Whitman's "Poem of Wonder at The Resurrection of The Wheat," published in the 1856 edition of Leaves of Grass. The poem, later retitled "This Compost," ironically questions notions of miasma only to conclude how wondrous nature's composting qualities truly are:

How can the ground not sicken of men?

How can you be alive, you growths of spring?

How can you furnish health, you blood of herbs, roots, orchards, grain?

Are they not continually putting distempered corpses in the earth? [....]

What chemistry!

That the winds are really not infectious! [....]

It grows such sweet things out of such corruptions,

It turns harmless and stainless on its axis, with such endless successions of diseased corpses,

It distils such exquisite winds out of such infused fetor,

It renews with such unwitting looks, its prodigal, annual, sumptuous crops,

It gives such divine materials to men, and accepts such leavings from them at last.

(LG 1856, 202-204)

In this instant "Chemistry" is now indeed not only a "large . . . constituent part of the earth," as Whitman stated in his 1847 review of Justus Liebig's Organic Chemistry, ${ }^{18}$ but the very basis of existence. Gone is the notion that the dead are "alive and well somewhere" (LG 1855, 17); now, they have become nutriment. The oddly distanced voice talking here is not the "I" of the 1855 Leaves that wants to "go to the bank by 
the wood and become undisguised and naked" ( $L G 1855,13)$, but a borrowed voice: Schele De Vere's. Toying with and acting out the professor's death-obsessed take on modern science, Whitman's "I" steps back to let Schele De Vere's claims enter Leaves of Grass-as early as 1856.

Though Schele De Vere's "Plant-Mummies" deals mostly with life and motion on land, the major part of Stray Leaves focuses on marine landscapes. Since Whitman shared with Schele De Vere a fascination for the watery element, these writings must have immediately appealed to him. One article by Schele De Vere, published in Putnam's in early 1855, must have particularly read like a poetic dare to Whitman. Titled "A Water Story,"19 the essay starts off with Schele De Vere in the midst of a hydrotherapy session: ${ }^{20}$ wrapped in wet cloth and unable to move, he starts reflecting upon the element of water "as it oozed in and out of every pore" (WS 192) of his body:

Enshrined in water, let us meditate its office, recall our walks by rivers, and our sensations in the midst of the ocean, our vigils on cliff and strand, with a boundless seaward landscape, the mystery of the tides, the fable of Arethusa, the enormous leviathan, and tiny nautilus, the luxury of a glass of iced Croton, and, what Mrs. Kemble calls 'ablutionary privileges.' Water! (WS 192)

Often lapsing into even longer associative catalogs-half a year before Whitman's prose preface to Leaves of Grass - Schele De Vere not only describes the properties of water, such as its "prismatic hues" (WS 196) but also calls it the "talisman of memory" (WS 193) and inevitably ties its appreciation to the poetic endeavor. "In fancy I abandoned myself to the world of waters" (WS 193), he writes, immediately leading him to see the "old Ocean's grey and melancholy waste" (quoting Bryant) rise before his eyes. More than any other setting, the ocean or river seems the appropriate realm of poetry:

How naturally do these associations glide into the verse of the poet! Each sings his favorite stream. The dolci acque inspired Petrarch at Vaucluse; Byron sang the 'blue and arrowy Rhone.' Can we behold the Danube and not think of the dying gladiator's 'young barbarians there at play; - they and their Dacian mother?' or the Thames, and not breathe a sigh to the memory of Thomson and Hood? (WS 196)

Apparently unable to name any American poets worthy of inclusion on this list, Schele De Vere avoids particulars when he talks of the ocean receiving "the household tribute of a native [i.e. American] bard" (WS 196) and, later on, even muses that "perhaps the indirect tributes of the bard most emphatically suggests the beauty of [the ocean]" (WS 196). For someone who would claim the title of American bard for himself, Whitman must have taken this as an imperative. 
Setting out to "claim" the American coast, Whitman writes "A Child's Reminiscence," a poem that would eventually enter Leaves in 1860 as "A Word Out of the Sea." In it, he puts himself in the tradition described by Schele De Vere and, quoting other famous poets, ${ }^{21}$ fuses his poetic awakening as a "native bard" with the memory of a childhood encounter at the sea shore. Still, in "singing" the ocean landscape off Paumanok, the weight of tradition - in the form of dozens of poets listed in Schele De Vere's article - is not lost on Whitman. In "As I Ebb'd with the Ocean of Life," a poem that would eventually become a companion to "Reminiscence" (later "Out Of The Cradle Endlessly Rocking"), Whitman discovers mockery in the ocean's movement. Picking up and expanding the image of "laughing water" (WS 194) that Schele De Vere used in "A Water Study," Whitman seems to hear all the distinguished poets and bards mocking his ambitions. And, while for Schele De Vere "abandoning" himself with water "ooz[ing] in and out of every pore" and noting its "prismatic hue" is an invigorating experience, Whitman's dissolving turns bitter:

(See! from my dead lips the ooze exuding at last!

See-the prismatic colors, glistening and rolling!) $(L G 1860,199)$

Instead of a feeling of transcendence and unity with other poets, as Schele De Vere experiences, Whitman seems to dissolve literally and turn into the "old ocean's grey and melancholy waste." In his moment of self-doubt, we find the poet "in drifts at your feet" ( $L G 1860,199)$. In light of the "blab" of Shakespeare, Tennyson, Petrarch, and Byron echoing loudly from the claimed ocean shores of Europe, his encounter with the landscape leaves him as "debris" and his attempt to fuse Paumanok with his name and poetic biography fails:

O baffled, balked,

Bent to the very earth, here preceding what follows,

Oppressed with myself that I have dared to open my mouth,

Aware now, that, amid all the blab whose echoes recoil upon me, I have not once had the least idea who or what I am [....] (LG 1860, 196-197)

While Schele De Vere's “A Water Study" seems to have played a major role in prompting Whitman's poetic entry into the elite realm of "shore poets" in 1860, the amateur naturalist also was instrumental in helping Whitman expand his poetic grasp from ocean shore to the deep sea itself. While Whitman's view of the ocean in 1855 seemed to have been strongly influenced by stories of sailors and fishermen, the 1860 Leaves depicts a much more diverse - and to Whitman highly problematic-ocean ecosphere. Besides the familiar old romantic images of 
whaling and "great monsters" ( $L G 1855,34)$ lurking below the waves, the poet now talks of corals and sea-leopards. This glimpse "below the brine," though, is, more than any other part of Leaves, borrowed from Schele De Vere.

In chapter three of Stray Leaves, titled "The Ocean and Its Life" (also published separately in Putnam's in 1855 and reprinted widely, including in Frank Leslie's New York Fournal, the Methodist-Episcopal Church's Home Circle, The Sailor's Magazine, and Odd Fellows' Literary Casket), Whitman would have discovered vivid and unusually beautiful depictions of life on the floor of the arctic ocean that differed quite drastically from contemporary beliefs - so much so, in fact, that the Catholic Magazine felt obliged to publish an article that reads like a rebuttal of Schele De Vere. Fitfully titled "Deep-Sea Desolation," it states that "despite the fanciful pictures which some writers have drawn of the ocean bed, its desolation ... must be extreme" and insists that "plants do not live in the deep sea." 22 Though the truth lies somewhere in between these two extremes, Whitman seemed to have been captured by Schele De Vere's eerie (though often fictional) submarine landscapes, full of thick forests, bright colors and strange animals that "seem to gratify every whim and freak" (SL 104). By copying the central images of the piece to his notes, ${ }^{23}$ including words like "turf" or "sluggish" that never appeared in Whitman's writings before, he condensed Schele De Vere's paragraph to poetry and claimed it as his own. Every single line of the poem later titled "The World Below The Brine" can be traced back to Stray Leaves, most obviously lines 1-10, describing this otherworldly oceanscape:

The world below the brine, ${ }^{24}$

Forests at the bottom of the sea,

the branches and leaves,

Sea-lettuce, vast lichens,

strange flowers and seeds, millions of briny drops $(90) ;{ }^{25}$ world beneath the waves (110); pillow of brine (114); briny ocean (104)

the bottom of the sea is covered with dense and ancient forests (110)

branches and leaves of firm, earth-rooted trees (101); irregular branches, which occasionally end in . . . leaves (103)

sea-lettuce (104); large, porous lichens (104)

a living, sensitive animal, clad in the ... bright colors of flowers (106); currents bring seed (109) 
the thick tangle,

openings, and pink turf,

Different colors, pale gray and green, purple, white, and gold,

the play of light through the water

Dumb swimmers there among the rocks,

coral, gluten, grass, rushes,

and the ailment of the swimmers,

Sluggish existences grazing there suspended,

or slowly crawling close to the bottom,

The sperm-whale at the surface blowing air and spray, or disporting with his flukes,

The leaden-eyed shark, the walrus, the turtle, the hairy sea-leopard, and the sting-ray,

Passions there, wars, pursuits, tribes, sight in those ocean-depths,

breathing that thick-breathing air, as so many do, thicket seems impenetrable (104)

large openings . . . where smaller plants form a beautiful pink turf (104)

playing in all the colors (104); green, gold and purple (104); fish in gold and silver armor [and]. . milk-white . . medusae (109)

bright flashes of light, and fitful rays (110)

glassy, colorless eyes stare ... with dull, imbecile light (111-112) [referring to fish]

half vegetable and half animal, the coral. (106); seaweed, slimy and dark, waves its arms (102)

nature pours out, with a lavish hand, living food, storing even the waves with nutriment for their gigantic denizens (142)

sluggish turtles (111); strange, ill-shapen forms . . graze peacefully (104-105); seals hang with their enormous tusks on large, tall trees (104)

Creeping close to the ground (104)

the dying whale throws his enormous carcass high into the air, driving the water up in lofty columns, capped with foam (97)

shark with his leaden eyes, the thickhaired sea-leopard, and the sluggish turtle (104); young walrus (105)

all become the representatives of so many human passions (116); no peace is found below . . . there reigns endless murder, wild warfare, and fierce bloodshed (96)

Each atom of water that comes in contact with its delicate gills, gives out its imprisoned air, to freshen and invigorate the creature's pellucid blood (106). 
It should be noted that even though Whitman mines only key phrases, the succession of these images is nearly identical to Schele De Vere's. There are only a few major changes like adding a sting-ray (or, perhaps, confusing it with the nautilus appearing in the original article) and specifying Schele De Vere's whale as a sperm-whale. The latter could either be an homage to Melville's Moby Dick or a sexualized reading of Schele De Vere's strikingly womb-like ocean floor. With its "pink turf," "thick tangle," and "openings" filled with sticky substances ("gluten"), the ocean's "dumb swimmers" seem to turn into embryonic figures in Whitman's eyes, "breathing that thick-breathing air" of the ocean's amniotic liquor and ultimately being birthed onto land to "change thence to the sight here." Through a careful selection and rearrangement of Schele De Vere's words, Whitman creates a sexualized image of the origin of species. This is all the more remarkable, considering that in Whitman's poetic compression the ocean seems to be inhabited largely by mammals (whale, walrus, two different seals) that, with their small appendices, seem to resemble unborn humans. Here, Whitman actually seems to suggest life moving out of the waters and onto land-an evolutionary insight that is generally understated in Stray Leaves.

Still, one of the major obstacles for reading "The World Below the Brine" as a science poem involves the last few lines, which talk about "beings from other spheres" that lend themselves nicely to angelic or spiritual interpretations:

The change thence to the sight here, and to the subtle air breathed by beings like us who walk this sphere;

The change onward from ours to that of beings who walk other spheres. (LG 1860, 235)

Ida Fasel, in the only analysis that seems feasible once we are aware of the source material for "The World Below the Brine," expands upon the idea of an evolutionary logic in the poem. "Carefully distinguishing between 'thick-breathing air' under water and 'subtle air' of 'beings like us'," Fasel writes, Whitman "shows the importance of environment and provides, in the absence of visual evidence, the basis for the final analogy of ongoingness of life on other planets." 26 Though belittled in A. James Wohlpart's more recent reading of the poem (he instead sees this third sphere as "spiritual existence in a transcendent state"27), Fasel's claim might actually be true to the source material.

In Stray Leaves, Schele De Vere devotes his final chapter, titled "A Trip To The Moon," to the idea of alien life-forms. In it, he critically examines contemporary misconceptions of lunar life and refutes scientific discoveries of possible forests or settlements on the moon's surface. Still, Schele De Vere concludes, that does not mean life on the moon is impossible or even improbable. Using phrases that Whitman echoes in 
the last lines of "The World Below the Brine," he argues that "inhabitants of [a world like the moon], if there be any, must have other bodies than ours, other blood must run through their veins, and other lungs breathe their air - we could never live in such a world" (SL 277). While the moon might not be ready yet to support life, it might just be a matter of time until the planetary forces of change transform its environment for the better: "there must come a time for the moon as for the earth, though perhaps after thousands of years only, when thinking, intelligent beings will rise from her dust" (SL 282), Schele De Vere concludes. By including this notion in "The World Below the Brine," Whitman expands the evolutionary grasp of Leaves of Grass from the time "nebula cohered to an orb" and "monstrous sauroids" ( $L G 1855,50)$ roamed its surface to the appearance of extraterrestrial life in millennia to come-possibly even long after humans walked the earth.

Still, while embracing contemporary notions of evolution even in realms as seemingly absurd as alien life, Whitman never fully accepts one of the major pillars of a particular evolutionary theory emphasized so strongly by Schele De Vere throughout Stray Leaves-Darwin's idea of the survival of the fittest. Though Darwin's opus magnus On the Origin of Species was yet to be published in 1855, one of Darwin's main tenets of evolution, natural selection, was already formulated. Developed in 1839 , this idea infused Darwin's geological writings as well as the famous journals of his travels on the H.M.S Beagle, all in print well before $O n$ the Origin of Species was published. Besides strikingly colorful descriptions of marine life that Schele De Vere calls "charming" (SL 107), these notebooks, first published in 1838 and undergoing major revisions in 1845, contain several passages like the following:

The varieties of man seem to act on each other in the same way as different species of animals - the stronger always extirpating the weaker. ${ }^{28}$

So even though the term "survival of the fittest" ${ }^{29}$ did not yet exist to describe the driving force behind evolutionary change, Schele De Vere found in Darwin's Beagle-journal a rich array of blueprints for the evolutionary elements he would emphasize in Stray Leaves. Understanding the drastic consequences of Darwin's still somewhat carefully formulated findings and encouraged by some of his at times gruesome depictionssuch as "crabs dragging ... young birds out of their nests, and devouring them" 30 - Schele De Vere paints a picture of evolution through violent strife and constant battle. Still, while the professor could simply exclude humanity from the troubling consequences of these observations, Whitman, the poet of the people, could not, and he struggled with how-or even, if - the Darwinian ideas that he gleaned from Stray Leaves could be fused into Leaves of Grass. 
Most obvious is this inner struggle in Whitman's poetic compression of "The Ocean And Its Life" into "The World Below The Brine." Even in its shortened, poetized form, the notion of "survival of the fittest" seems to vibrate in between the lines, leading, for example, Joseph Beaver to state that "in connection with Darwin's 'Struggle for Existence' . . . the line in 'The World below the Brine' which speaks of the passions, 'pursuits' and 'wars' in the sea would seem to be [a] very plain statement." ${ }^{.1}$ A glance at the original passage seems to justify Beaver's claim:

The ocean is a vast charnel house. There are millions and millions of animals mouldering, piled up, layer upon layer, in huge masses, or forming mile-long banks. For no peace is found below, and under the thin, transparent veil, there reigns endless murder, wild warfare, and fierce bloodshed. Infinite, unquenchable hatred seems to dwell in the cold, unfeeling deep. Destruction alone maintains life in the boundless world of the ocean. Lions, tigers, and wolves, reach a gigantic size in its vast caverns, and, day after day, destroy whole generations of smaller animals. Polypi and medusae, in countless numbers, spread their nets, catching the thoughtless radiati by tens of thousands, and the huge whale swallows, at one gulp, millions of minute, but living creatures. The swordfish and the sea-lion hunt the elephant and the rhinoceros of the Pacific, and tiny parasites dart upon the tunny fish, to dwell in myriads in his thick layers of fat. All are hunting, killing, murdering. (SL 96-97)

Schele DeVere's eloquent celebration of destruction and bloodshed is too much for Whitman to absorb. Survival of the fittest in graphic detail"nature red in tooth and claw," as Tennyson famously put it - contradicts too much of what Whitman already poetized about the development of life. For him, evolution was largely an anthropocentric, relatively harmonic endeavor. In Whitman's poetics, mankind does not advance by adapting to its environment in a violent struggle with other species and under constant strain to "outperform" fellow humans for the chance to mate, but through a loving, "cumulative" (LG 1891/92, 420) process:

Out of the dimness opposite equals advance .... Always substance and increase, Always a knit of identity .... always distinction .... a always a breed of life. (LG 1855,14$)$

As Whitman believes in an eternal "law of the living" ( $L G 1855,68)$ that applies to all beings on earth including humans, he cannot imagine infusing scenes of nature-sanctioned killing of the weak, so vividly depicted by Schele De Vere, into Leaves. Instead, he argues that weakness can be part of human development through a "culmination" of deficits into a greater good. In a typical move for the 1855 Leaves, Whitman demonstrates this claim by sketching his own poetized genealogy of "culmination": 
Through me many long dumb voices;

Voices of the interminable generations of slaves,

Voices of prostitutes, and of deform'd persons,

Voices of the diseas'd and despairing, and of thieves and dwarfs,

Voices of cycles of preparation and accretion. . . . (LG 1855, 29)

By remaining on a human level and ignoring the gruesome lessons Schele De Vere discovers "below the brine," Whitman avoids dealing with natural forces that seem to contradict (or correct) his life-affirming view of evolution. Though Schele De Vere generally shares an optimistic outlook on evolution with Whitman, arguing that "creation [is] ... daily growing nobler, more varied, more spiritual" (SL 282), it seems impossible for Whitman to agree that such a result is to be achieved through "endless murder, wild warfare, and fierce bloodshed" (SL 96). Whitman's silence on one of the main tenets of modern evolutionary theory-survival of the fittest-is therefore not a stylistic decision, as Beaver suggests by claiming that "such doctrines do not lend themselves so easily to poetic use." 32 Whitman's "law of the living," though evolutionary, is clearly not Darwinian (or Schele De Vere-ian), but a semi-Lamarckian"33 "law of promotion and transformation" ( $L G 1855,68)$.

Still, Stray Leaves and its author influenced Leaves of Grass on more than just a textual level. Besides providing Whitman with a grim, biological perspective on life that he could play with, use and struggle against, Stray Leaves also appealed to Whitman as a material object. Above all, it was one thing: a very well crafted piece of bookmaking. Boasting a large variety of typefaces, design elements, and custom spine decorations, it would have immediately appealed to Whitman the printer. Taking a closer look at the spine of Schele De Vere's book, one discovers striking similarities to the "spermatic imagery" 34 Whitman used on the cover and title-page of the 1860 Leaves. (See Figures 2 and 3.) Whatever the intent of the cover design for Stray Leaves, it does not seem surprising that Whitman would have perceived spermatozoa tails protruding from the letters and would have adapted the idea for his book (bottom left image). As Schele De Vere's narrative of the ocean floor turns erotic in Whitman's rendering, so does the root-design on the spine of Stray Leaves. Even the "plain letters, graceful and flowing but with odd flourishes" 35 on the 1860s cover of Leaves (right image) that Ed Folsom describes in his analysis of Whitman's spermatoid design elements, seem to have found their origin in the spine design of Stray Leaves. We find not only another "plain" all-caps font ${ }^{36}$ but also a similarly playful letterextension. The lower extensions of the " $\mathrm{A}$ " in "STRAY" and the "R" of "GrASs" (from the cover design) appear as mirror images of each other. Both words also show similarly exaggerated swooping upper curves of 


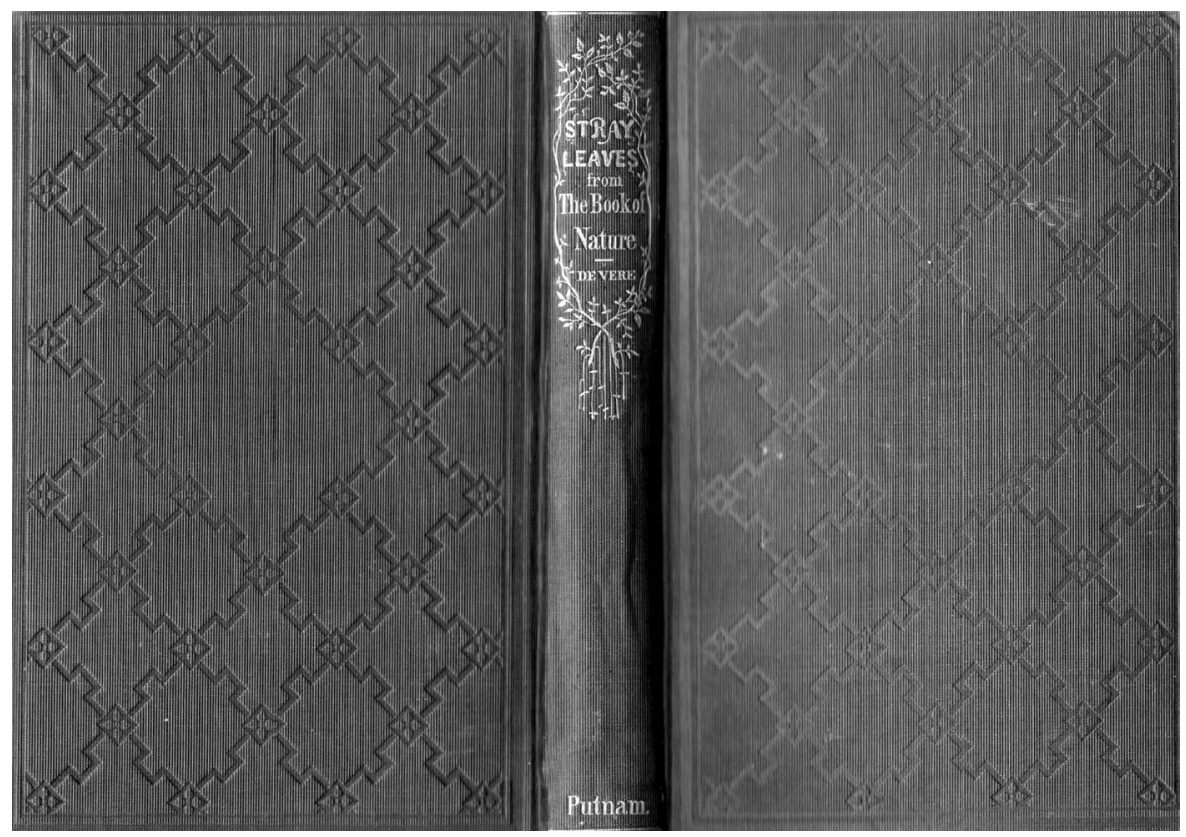

Figure 2: Cover and spine of Stray Leaves.
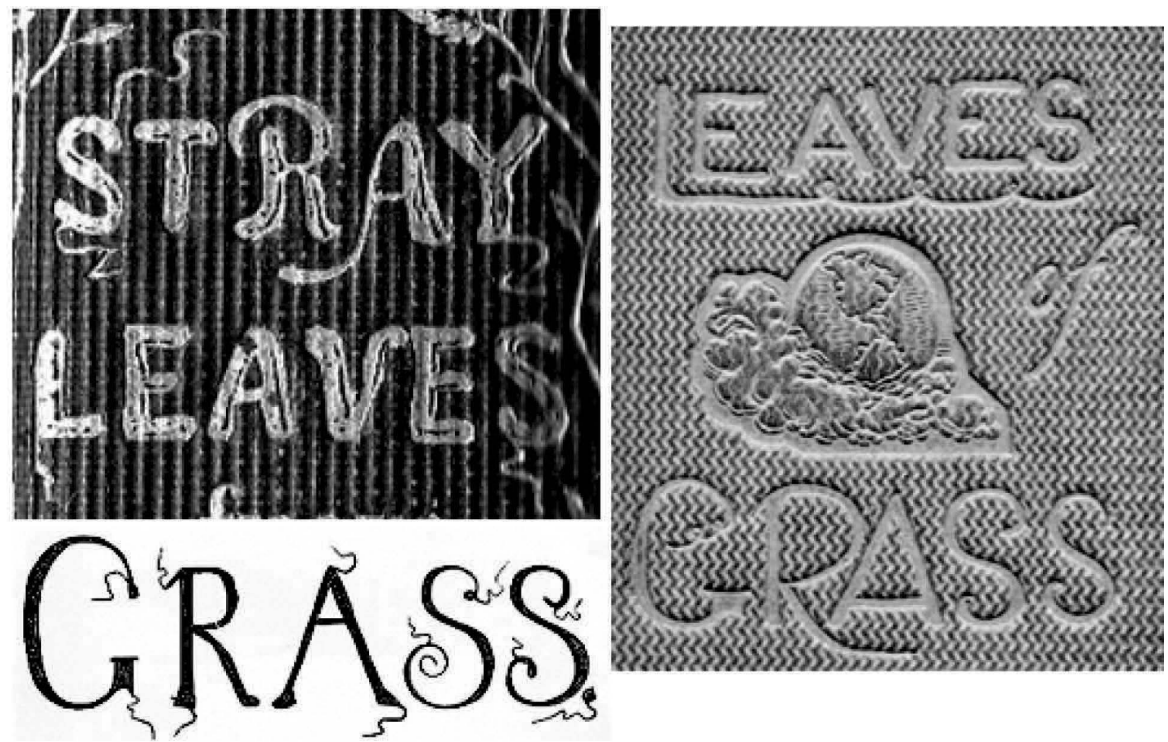

Figure 3: Top left: Stray Leaves spine (detail); right: cover 1860 Leaves of Grass; lower left: title page 1860 Leaves of Grass (detail). 
STRAY LEAVES

nox max

BOOK OF NATURE.

I.

6itilu a febble.

"All Gatare wideas upward Erermore

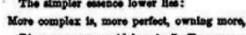

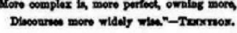

A WAY out in Mesopotamis, the traveller vast A plains unroll themselves before his wondering eye, and scattered over them many a grassy knoll with its flock of goats and camels. No one suspected that under those hills lay buried the ancient glory of Nineveh, “ an exceeding great city of three dsys' journey, wherein are more than six score thousand persons." Like the faint echo of distant thunder, a few half-forgotten nsmes and vague, dream-like legends, were all that had come down

Figure 4: Opening page of Stray Leaves. enonom

CH A N T S

\section{DEM OCRAT I C}

Axp

NATIVE AMERICAN.

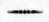

Apostroph.

0 mater! 0 fils !

0 brood continental !

0 flowers of the prairies!

O space boundless! $O$ hum of mighty products !

0 you teeming cities! 0 so invincible, turbulent, proud!

0 race of the future! 0 women !

$O$ fathers! O you men of passion and the storm!

0 native power only ! 0 beauty!

0 yourself ! $O$ God ! $O$ divine average !

0 you bearded roughs! 0 bards! 0 all those slumberers!

0 arouse! the dawn-bird's throat sounds shrill! Do you not hear the cock crowing?

0 , as I walk'd the beach, I heard the mournful notes foreboding a tempest - the low, oft-repeated shriek of the diver, the long-lived loon;

Figure 5: Page from the 1860 Leaves of Grass.

the "R": in "STRAY" the curve makes the letter much higher than the rest; in "GRASs" it almost seems to touch the " $\mathrm{A}$ " to its right.

In addition to the bindings, the page designs of both books share remarkable similarities, using some of the same typefaces and showing a similar mixing of sizes and stylistic elements. Both main bodies of text are printed in Scotch Roman, a popular font of the time, and use Elzevir type for some of the headings (for example, Whitman's title for the poem "Walt Whitman"). (See Figures 4 and 5.) Both main texts are justified while their titles are larger than the rest of the text, centered and followed by a visual separator - usually a variation of a line with a round object in its center: ${ }^{37}$

In a move characteristic of Whitman's embrace of Schele De Vere, these simple stylistic elements take on a different meaning in Whitman's hands, either giving off sexual suggestions (could the image above then show two sperm-cells about to fertilize an egg?) or hinting at issues discussed in the poem to follow (as Ed Folsom suggests). 
Still, some of these similarities might be due to printing trends in the mid-nineteenth century. As Barbara Henry shows in her analysis of the types used in the 1860 edition of Leaves, ${ }^{38}$ other books by Thayer and Eldridge, the publisher of the 1860 Leaves, show similar design elements. The same is true for most G.P. Putnam \& Co. publications of the 1850 s stereotyped by Manhattan's Billin \& Brothers. ${ }^{39}$ Still, even the books from both typesetters most similar to Leaves of Grass (1860) or Stray Leaves-Putnam's Carl Krinken ${ }^{40}$ and Thayer and Eldridge's Happy Hours at Hazel Nook $k^{41}$ - are not as similar to either of these books as Whitman's 1860 edition is to Stray Leaves. The somewhat odd use of heavily ornamented type ${ }^{42}$ in between standard types (see images above) especially seems to be a feature unique to each book when compared to the back catalogues of their respective printing houses. In its layout and choice of typeface, Schele De Vere's book was by any means a book with an extraordinary design for the mid-1850s. In light of it, Whitman's 1860 edition seems like a conscious attempt to top the stylistic innovations of Stray Leaves and take them a step further. Given the textual influence that Stray Leaves had on Leaves of Grass, it may well be the case that Whitman used Schele De Vere's 1855 book as a guide when he perused the L. Johnson specimen book, trying to decide on a radical new look for his revised, restructured, and drastically expanded edition of Leaves.

It is also interesting to note how the poems influenced by (or based on) Schele De Vere's writings enter Leaves of Grass. Given the strong notions of doubt running through these pieces-one hinting at natural selection and the possibility of life after man ("The World Below the Brine"43), one literally indulging in materialism ("This Compost"), and the other reminding the poet of his own shortcomings ("As I Ebb'd with the Ocean of Life") - it appears that Whitman initially tried to balance their impact by coupling them with earlier, more spiritual pieces. In light of Stray Leaves, the whole "Leaves of Grass" cluster in the 1860 Leaves, which contained all three of these poems, reads almost like a discussion between the two books. Considering the curiously redundant name of the cluster, one wonders whether the title might actually be a double plural. Could it indeed be Leaves of Grass meets Stray Leaves from the Book of Nature? For every piece of Schele De Vere-induced gloom, Whitman counters with two or three life-affirming pieces, mostly from the 1855 Leaves, such as "Song of the Answerer" or "Great Are the Myths." So when Roy Harvey Pearce argues that the cluster shows Whitman struggling with "too much reality" and countering it with "sentimentality," 44 he might indeed be describing Whitman's attempt to cushion the impact of what he had recently absorbed from Schele De Vere. Still, while coupling contradictory statements in Whitman's individual poems works, it fails as a strategy in "Leaves of Grass." Incoherent and seemingly disorganized, this prominently placed cluster feels oddly pointless 
and random. But this effect may be the result of Whitman's attempt to absorb Schele de Vere's "endless murder" (SL 96) and bleak lessons into his poetics.

Eventually, though, Whitman realized that his balancing act had failed and he later rearranged the Schele De Vere-inspired poems, moving them all (except for the ironic "This Compost") to a cluster exclusively devoted to doubt. Titled "Sea-Drift" in the 1881 edition of Leaves, this cluster would not only reunite "As I Ebb'd" with "Out of the Cradle" but would also create one of the darkest groupings in any edition of Leaves. With humanity reduced to archetypal, biographic figures (the father, the child, vague shadows), this cluster depicts landscapes devoid of the vibrancy of human life that Whitman so loved to catalogue. Instead, we see a solemn Whitman, doubting his role as a poet and looking at an ocean that seems to whisper of the agony of generations of human ancestors fighting and dying below the brine. Ultimately, Whitman's evolutionary faith - vibrating so strongly in earlier editions - is reduced in "Sea-Drift" to imagining "beings" who will "walk other spheres" ( $L G 1891 / 92,207$ ) in millennia to come. Encapsulating a moment of doubt in himself and in humanity, Whitman's "Sea-Drift" finds solace only in vast cosmic processes. It does not celebrate the United States, democracy, or even humanity in its broadest sense. Instead, it clings to the little solace nature has to offer: the immortality of physics. As Schele De Vere described it:

The great cosmic powers, light and heat [will]... send their waves through the wide ocean of the world, and play against the shores of all of its gigantic islands. There is, no doubt, vital power in them, and at the proper time, at His bidding, life will spring forth and order will reign, where now destruction and chaos alone seem to rule supreme. (SL 282-283)

In the end, only a cluster like "Sea-Drift" could sustain the pressure “oozing" from Schele De Vere's Stray Leaves as Whitman tried to absorb it into his poetry. From his early, playful use of Schele De Vere's "mephitic vapors," through his gaining inspiration from the book's physical appearance, to his infusing Stray Leaves' oceanity into his poetry, Whitman wrote Stray Leaves into Leaves of Grass. Though this endeavor ultimately faltered, Schele de Vere nonetheless pushed Whitman into some daring poetic terrain, enriched his language, and prompted him to make some fascinating design choices for his book.

Technische Universität Dortmund 


\section{NOTES}

1 See Betty Barrett, “'Cavalry Crossing a Ford': Walt Whitman's Alabama Connection," Alabama Heritage 54 (Fall 1999), 6-17; and Ted Genoways, "Civil War Poems in 'Drum-Taps' and 'Memories of President Lincoln,"' in A Companion to Walt Whitman, ed. Donald D. Kummings (Malden, MA: Blackwell, 2006), 522-538; and Genoways, Walt Whitman and the Civil War: America's Poet During the Lost Years of 1860-1862 (Berkeley: University of California Press, 2009).

2 Maximilian Schele De Vere, Stray Leaves from the Book of Nature (New York: G. P. Putnam \& Co, 1855). Hereafter, $S L$.

3 Jerome Loving's biography, for example, mentions it once in passing, and Reynolds's not at all. See Loving, Walt Whitman: The Song of Himself (Berkeley: University of California Press, 2000), 179.

4 The quotation and biographical data come from John S. Patton, "Maximilian Schele De Vere," Library of Southern Literature: Biography XI, ed. Edwin Anderson Alderman, Joel Chandler Harris, Charles William Kent (Atlanta, GA: The Martin and Hoyt Company, 1907), 4687.

5 Schele De Vere was a member of the American Oriental Society. See "Back Matter," Fournal of the American Oriental Society 13 (1889), cccxviii-cccxxiii.

6 Later in his life, Schele De Vere would even write a book titled Modern Magic (New York: G. P. Putnam \& Co, 1873) to investigate the "existence of certain laws. . . not accessible to us by means of our ordinary senses" (3).

7 C. Carroll Hollis, "Whitman and William Swinton: A Co-operative Friendship," American Literature 30 (January 1959), 425-449.

8 Walt Whitman, Notebooks and Unpublished Prose Manuscripts, ed. Edward F. Grier (New York: New York University Press, 1984), 4:1432, 5:1651.

9 James Perrin Warren, Walt Whitman's Language Experiment (University Park: Pennsylvania State University Press, 1990).

10 William Swinton, "Rambles over the Realms of Verbs and Substantives," Putnam's Monthly Magazine of American Literature, Science and Art 4, Issue 23 (November 1854), 472-481, and Issue 24 (December 1854), 602-610.

11 Charles Eliot Norton, Review of Leaves of Grass (1855), Putnam's Monthly: A Magazine of Literature, Science, and Art 6 (1855), 321-323. Whitman was fully aware of this review and reprinted it in his 1856 annex to Leaves of Grass titled "LeavesDroppings" and in his 1860 promotional leaflet Leaves of Grass Imprints.

12 "This story - I think it was this - was printed in the first number of Putnam's Magazine - the revised Putnam's - if I am not mistaken. . . Putnam's, then, had, I suppose, as many or nearly as many pages as the present Century." Whitman, quoted in Horace Traubel, With Walt Whitman in Camden (various publishers, 1906-1996), 5:364. Available on the Walt Whitman Archive (www.whitmanarchive.org).

13 “Notes on New Books," Daily National Intelligencer (October 11, 1855).

14 Walt Whitman, Leaves of Grass (1855), 17. Hereafter, LG 1855. Available on the Walt Whitman Archive (www.whitmanarchive.org).

15 “Miasma Over Cities,” Boston Investigator (November 10, 1847), Issue 27. 
16 Robert Koch would effectively put an end to this idea in 1876 with the publication of his study on the life cycle of Bacillus anthracis. Before Koch, even Darwin identified "miasma" as the cause for various types of illnesses occurring in areas surrounding stagnant bodies of water. See Darwin, Fournal of researches into the natural history and geology of the countries visited during the voyage of H.M.S. Beagle round the world, under the Command of Capt. Fitz Roy, R.N. 2nd. Ed., (London, UK: John Murray, 1845), 365. Hereafter, Fournal.

17 Maximilian Schele De Vere, "Plant-Mummies," Putnam's Monthly Magazine of American Literature, Science and Art 6, Issue 31 (July 1855), 26-32.

18 Walt Whitman, Review of Justus Liebig's Organic Chemistry in its application to Agriculture and Physiology, Brooklyn Daily Eagle (June 28, 1847).

19 Maximilian Schele De Vere, "A Water Story," Putnam's Monthly Magazine of American Literature, Science and Art 5, Issue 26 (February 1855), 192-196. Hereafter WS.

20 A practice then marketed as "water cure." Another famous recipient of said cure was Charles Darwin.

21 See Michael Vande Berg, “'Taking All Hints to Use Them': The Sources of 'Out of the Cradle Endlessly Rocking,"' Walt Whitman Quarterly Review 2, (Spring 1985), 1-20.

22 Quoted from "Deep-Sea Desolation. The Ocean Bed a Desert of Ooze and Slime after the First Mile in Depth (News)," The Milwaukee Sentinel (November 9, 1888), 2.

23 The notes, written sometime between 1857 and 1859, show no signs of hesitation or any corrections, strongly suggesting note-taking rather than composing; Whitman selects key phrases and adds connecting tissue. These notes are available in the Integrated Guide to Walt Whitman's Poetry Manuscripts ("The World Below the Brine") on the Walt Whitman Archive (www.whitmanarchive.org), under "Poetry Manuscripts."

24 Quoted is the deathbed-version of the poem with an added title/first line. LG 1891/92, 206-207.

25 Page numbers refer to Stray Leaves. All chapters were published in identical versions as articles in Putnam's Magazine.

26 Ida Fasel, "Whitman's World Below The Brine," Explicator 25 (1966), 1.

27 A. James Wohlpart, "From the Material to the Spiritual in the Sea-Drift Cluster: Transcendence in 'On the Beach at Night,' 'The World below the Brine,' and 'On the Beach at Night Alone,'” Walt Whitman Quarterly Review 13 (Winter 1996), 154.

28 Darwin, fournal, 345.

29 The term "survival of the fittest," though, was coined by Herbert Spencer and was not used by Darwin himself.

30 Darwin, fournal, 10.

31 Joseph Beaver, Walt Whitman-Poet of Science (New York: King's Crown Press, 1951), 113-114.

32 Beaver, 113.

33 On Whitman's evolutionary beliefs, see David Charles Leonard, "Lamarckian Evolution in Whitman's 'Song of Myself,"' Walt Whitman Review 24 (1978), 21-28. 
34 Ed Folsom, Whitman Making Books / Books Making Whitman (Iowa City, IA: Obermann Center for Advanced Studies, 2005), 18.

35 Ed Folsom, “'A spirt of my own seminal wet': Spermatoid Design in Walt Whitman's 1860 Leaves of Grass," Huntington Library Quarterly 73 (2010), 586.

36 With the exception of the "of" in "LEAVES OF GRASs" that has no corresponding element in "STray Leaves."

37 Detail from Stray Leaves (left, SL 1) and detail from the 1860 "Calamus 27" (right, $L G$ 1860, 369).

38 Barbara Henry, "The Design and Typography of Leaves of Grass (1860)," Huntington Library Quarterly 73 (2010), 601-612.

39 Depending on the date of the publication, "Brother" is either listed in singular or plural. Page one of Stray Leaves lists the printing company as follows: "Printed and Stereotyped by Billin \& Brother, 20 North William Street, N. Y.”

40 Susan Warner and Anna Bartlett Warner, Carl Krinken: His Christmas Stocking (New York, NY: G. P. Putnam \& Co, 1854).

41 Harriet Farley, Happy Hours at Hazel Nook: or, Cottage stories (Boston, MA: Wentworth \& Co., 1854). Barbara Henry lists the book as a possible source for $L G$ 1860 design elements.

42 In Whitman's case-as Barbara Henry shows-Arabesque type, in Schele De Vere's case a variation of an Old English type.

43 Names taken from the 1891-1892 deathbed-edition. In the 1860 Leaves they are sections of the "Leaves of Grass" cluster.

44 Roy Harvey Pearce, "Introduction," Leaves of Grass: Facsimile Edition of the 1860 Text (Ithaca, NY: Cornell University Press, 1961), xxxii-xxxiii. 